УДК 7.033.2 (497)

ББК 85.14

DOI:10.18688/aa155-2-30

Anđela Đ. Gavrilović

\title{
The Tricephalos in the Painted Dado of the Church of Nova Pavlica - Possible Origin of Iconography References ${ }^{1}$
}

In the sanctuary area of the church of the Presentation of the Virgin in the Nova Pavlica (Serbia), under the figure of St John the Chrysostomos, there is one magnificent representation of tricephalos, located in the left framed dado panel (Ill. 56). It was discovered in the painted layer dated before 1386. In the previous research articles, this fresco is only scarcely mentioned, and up to the present day there wasn't any significant study dedicated to it. Therefore, we believe that it deserves an adequate attention. We intend to analyze the representation of the tricephalos, trace back its iconography and find possible origins of different attributes which shape the image of this fantastic creature.

In previous bibliography, three authors referred to this tricephalos.

Milorad Mihailović only states that one fantastic animal is illustrated in the sanctuary area of the church, simulating sculpture [4, p. 41].

Ivan M. Đorđević notices that in the frescodecoration of Nova Pavlica "we encounter few examples of the surviving antiquity", among which the fragments of "the painted dado with human and animal representations", which "suggest loans from late antique art" [3, p. 27]. He offers the observation that the tricephalos in the sanctuary of Nova Pavlica is "an apocaliptic, undefined, sea monster, created as the type at the end of the $12^{\text {th }}$ century" [3, p. 38]. As the analogies, he mentions the "lion-Ocean" in the scene of Ascension of Christ from Kurbinovo monastery, as well as the personification of the Earth from the scene of Last Judgment from Holy Saviour church in Neredica and the figure of lion in the scene of Last Judgement from Gračanica [5, LXXIa].

In one statement, Branislav Cvetković refers to the said tricephalos as "Okeanos who is spitting water", not expounding his view at all [2, p. 123]. However, on the basis of the photo we have, we can not say whether the lion from Nova Pavlica is spurting water, because the lower part of the fresco is completely destroyed.

With the aim of scrutinizing the statements we mentioned before, we will direct our own research towards the detailed examination of the iconography of the tricephalos from Nova Pavlica. Since this is the rare example of this motif in both Serbian medieval and Byzantine art, as well as the lack of detailed research in this field, adequate attention should be devoted to this particular motif.

The present paper contains the results of the work on the Project no. 177036 - Serbian Medieval Art and Its European Context - supported by the Ministry of education, science and technological development of the Republic of Serbia. 
If we were to divide the tricephalos from Nova Pavlica into component parts, we could say that it is composed out of three "mask motives". By the term mask motif, we mean the antique detail in medieval painting in the form of an animal, most often a lion head or a human head [6, p. 308]. In many instances, one can not make a clear distinction between the lion and the human head.

The central figure of tricephalos in Nova Pavlica has the lion head, two horns on it, two ears, widely open eyes and an elongated lion nose. The appearance of the upper part of this central figure corresponds to the upper part of the bull in appearance. The central head represents the compositional center of the panel from which veins of marble stretch. Two young faces depicted in profile lean on the central head. These side figures are depicted in profile as beardless heads of youths, with hair on the head, emphasized big eyes and gaze. They are represented with accentuated foreheads, big noses, emphasized lips, teeth and chins, but without necks, so they seem to assume a caricatural form. Generally, the tricephalos has three heads, four eyes, three noses, three mouths, two horns and two ears. All the aforesaid figures are painted in a warm orange-ocher color of the marble revetment, following it up and continuing to it. The most prominent parts of all three faces, as well as the most accentuated marble veins are done in white lines. On all four sides, the dado panel is bounded with the rim forming a zigzag motive. It is flanked by two small red pillars with painted marble pattern ornaments, and above it, there is a dark blue frieze with the same painted motives of flowers and leaves that run along.

As one can see, the tricephalos in the dado of Nova Pavlica has quite an unusual appearance, and if it is to be judged by all visual details assembled into a whole, he has no perfect analogies in Serbian medieval art and in broader sense in the art of Byzantine world. Yet, the closest preserved visual analogy to the motive of tricephalos in Nova Pavlica in Serbian medieval art is found in the church of the Holy Apostles in Peć, in the dado in the south choir (Ill. 53) [2, p. 123].

Painted representation from Holy Apostles from Peć (Ill. 53), according to the number of common attributes and features, truly, most closely resembles the tricephalos from Nova Pavlica. It is a fantastic, tricephalos mask, which except for the central face, which in Pavlica has the features of a lion, and in Peć of an old man, has all the other characteristics in commun: human, caricatural, side profiles (with hair in Nova Pavlica, however), horns on the head of the central tricephalos, a similar warm monochrome tone (background), in which the whole square field is painted.

Beside the already mentioned statements of Ivan Đorđević, we would also like to underline another conclusion of his, that we find important in the context of the ancient legacy present in Byzantine and Serbian medieval art [3, p. 38]. Analyzing the lion masks painted on the capitels of Nova Pavlica, he makes the observation that the painters from this church very clearly expressed the idea of water deity by depicting a sea monster, "whose appearence was somewhere between Ocean and the lion" [3, p. 38]. If one considers the central figure of the tricephalos from Nova Pavlica, one may conclude that it in fact corresponds to the figure of the "lion-Ocean", whose appearence resembles the one of the human and the lion. In general traits, it is the representation of the ancient mask, which we often encounter in Byzan- 
tine and Serbian medieval wall painting as façade "ornament" on the painted architecture, as "ornamental decoration" of the pillars of certain stylites, or as "a marble relief ornament" of certain painted sarcophagi. However, one of quite unusual attributes of the central figure of the tricephalos from Nova Pavlica are its horns. Animals similar to the central figure of the tricephalos have either round or sharpened ears.

The motif of the so called "lion-Ocean" from Kurbinovo (Ill. 54) clearly shows that this mythological being has horns on his head, like the figure from Nova Pavlica, which is very rare, thus showing an exception. We believe that the assumption that the central lion figure from Nova Pavlica could have got his horns as a "special attribute" of personified, allegorical representation of certain "water", whose archetype could represent Acheloo or Okeanos. Namely, in ancient Greek art, the representations of the river Acheloo and Okeanos were de-

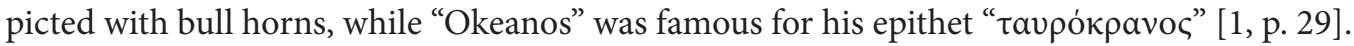
In Nova Pavlica the lion has the attributes of a bull - horns, ears and the upper part of the head. Such iconography could possibly indicate that the represented creature from Nova Pavlica is indeed the image of water. Its distant iconographic analogies, as far as the motif of horns is concerned, could be found, for instance, in the personification of the sea from the scene of Last Judgment from Torcello [5, fig. 4]. The tricephalos from Peć could perhaps indicate that the central figures from Nova Pavlica and Peć represent a certain kind of "visual synonyms". The Okeanos was in ancient times depicted in the form of human face with bull-horns, while here we see a lion with bull horns and ears. It is highly probable that the depiction of lion is some kind of visual synonym for the representation of the human head with horns. The iconography of the central figure of the tricephalos from Peć, done around the same period (around 1374), could lead us towards such an assumption. However, one can not say what was the exact meaning of this representation. We hope that further research could give an answer to this question.

Title. The Tricephalos in the Painted Dado of the Church of Nova Pavlica - Possible Origins of Iconography.

Author. Anđela Đ. Gavrilović — PhD, Research Associate. University of Belgrade, Čika Ljubina 18-20, 11000 Beograd, Serbia. andjela1321@gmail.com

Abstract. The fantastic tricephalos in the painted dado of the sanctuary area of the church of the Presentation of the Virgin in Nova Pavlica, the endowment of Musić brothers, is depicted on the fresco layer dating before 1386. It is utterly unusual and interesting because of its iconography. It does not have any perfect analogy neither in Serbian monumental painting, nor in the Byzantine art in general. In previous literature it was referred to as "a fantastic animal", "an apocalyptic, undefined, sea monster", as "an Okeanos which is spitting water". However, any further iconographical details of this fresco were not examined at all, which would be the aim of this paper. The appearance of the said tricephalos indicates that the origin of the various details of its iconography could be traced back to the ancient Greek and late antique art.

Keywords: Tricephalos; painted dado; Serbian medieval wall painting; the church of Nova Pavlica; $14^{\text {th }}$ century.

Название статьи. Изображение трицефала во фресковых композициях церкви в Новой Павлице - возможные варианты происхождения иконографии.

Сведения об авторе. Гаврилович Анджела Дж. - Ph. D., научный сотрудник. Белградский университет, Чика Љубина 18-20, 11000 Белград, Сербия, 11 000. andjela1321@gmail.com.

Аннотация. Во фресковой росписи нижнего регистра церкви Введения во храм Пресвятой Богородицы в Новой Павлице, датируемой до 1386 г., нам открывается изображение трицефала, поражающее необычностью иконографии. Ничего похожего в христианских храмовых росписях Сербии и других регионов в ареале византийского культурного наследия не встречается. В предшествующих исследованиях данное изображение трактовалось как «фантастическое животное», «апокалиптическое морское чудовище», «Океан, изрыгающий воду», однако детальный иконографический анализ этой фрески до настоящего времени не проводился. Это и стало целью данного исследования, в котором автор приходит к выводу о греческом и позднеантичном происхождении многих иконографических деталей такого рода изображений. 
Ключевые слова: трицефал; фресковая композиция; сербская средневековая настенная живопись; церковь в Новой Павлице; XIV век.

\section{References}

1. Brommer F. Okeanos. Archäologischer Anzeiger, 1971, no. 86/1, pp. 29-30.

2. Cvetković B. Manastir Nova Pavlica: Istorija, arhitektura i živopis [nepublikovana doktorska disertacija] (History, Architecture and Painting [unpublished DPhil]). Beograd, Filozofski fakultet. 2009. 123 p. (in Serbian).

3. Đorđević I. Zagonetni lik na kapitelima u novoj Pavlici. Studije srpske srednjovekovne umetnosti (Medieval Art of Serbia. Research data). Beograd, Zavod za udžbenike Publ., 2008, pp. 26-42 (in Serbian).

4. Mihailović M. Kovačević M. Nova Pavlica. Beograd, Republički zavod za zaštitu spomenika culture Publ., 1989. 63 p.

5. Mijović P. La pérsonification de la Mer dans le Judgment dernier à Gračanica. Charistērion eis Anastasion K. Orlandon (Charistirion to Anastasios K. Orlandos). Athēna, 1976, pp. 208-219 (in French).

6. Mouriki D. The Mask motif in the Wall Paintings of Mistra. Cultural Implications of a Classical Feature in Late Byzantine Painting. Deltion tēs Christianikēs Archaiologikēs Etaireias (Bulletin of the Christian Archaeological Society), 1980-1981, no 10, pp. 307-338. 